\title{
Editorial
}

The Editorial Board is pleased to publish and disseminate the "Journal of APF Command and Staff College", Volume 4, Issue 1, 2021. We believe that the contributions by the authors in this issue reflect conceptual, theoretical and empirical research works in their respective fields. The researches have been confined to ethos of security, development and peace spectrum. It encompasses articles from scholars, researchers and practitioners aligning it with contemporary issues and security related dynamics of modern era. Professors, academics, researchers, policy makers and students may seize learning opportunity and will highly be benefited from the articles included in the journal. The editorial board reserves the right to edit, moderate or reject the article submitted.

The articles included in this journal are mostly research based. Views expressed in the articles are purely personal and academic opinion of the authors and are not necessarily endorsed by APF Command and Staff College and the Editorial Board. We would like to express sincere thanks to all the contributors for their respective inputs.

\section{The Editorial Board}

Journal of APF Command and Staff College APF Command and Staff College Sanogaucharan, Kathmandu, Nepal 